\title{
PERSEPSI CITRA TUBUH, KECENDERUNGAN GANGGUAN MAKAN DAN STATUS GIZI PADA REMAJA PUTRI DI KOTA JAMBI
}

\author{
Merita, Nurainun Hamzah*, Djayusmantoko \\ Program Studi Ilmu Gizi, Sekolah Tinggi Ilmu Kesehatan Baiturrahim Jambi. Jl. Prof. M. Yamin, SH No. 30 Telp. 0741-33030. Jambi. Indonesia. \\ *Penulis Penanggungjawab: E-mail: nurainunhamzah97@gmail.com
}

\begin{abstract}
Background: The most common nutritional problems that occur in adolescents are underweight and obese caused by perception of body image and the tendency of eating disorders

Objectives: The purpose of this study was to determine the relationship between body image perception and eating disorders with nutritional status adolescent girls in High School in Jambi City, 2019.

Methods: This study used cross sectional study design that was carried out in 10 of high school in Jambi City on March until May 2019. The population in this study was all adolescent girls in Jambi City High Schools, that amounts 9,530 people. The sample was used 384 adolescent girls with cluster random sampling techniques. Data collection was using tools such as BSQ-16 for body image perceptions, Eat-26 for eating disorders, and measuring nutritional status (BMI/A) with weight scales and microtoice. The analysis was carried out with univariate analysis and bivariate analysis (spearman correlation test).

Results The results showed that the majority of adolescent girls had a normal nutritional status (83.1\%), a positive body image (64.6\%), and as many as (82.8\%) adolescent girls did not have symptoms of eating disorders. Correlation analysis showed that there was a relationship between body image perception with the nutritional status of BMI/A indicator (p-value 0.000), but there was no correlation between the eating disorders with the nutritional status of the BMI/A indicator ( $p$-value 0.657; $r=0.443$ )

Conclusion: It can be concluded that most adolescent girls have a positive body image and have a eat disorders and nutritional status is normal. Therefore, young women must be confident in the current body condition so that it does not lead to eating disorders and cause nutritional problems.
\end{abstract}

Keywords : body image perception; eating disorder; nutritional status; adolescent girls

\begin{abstract}
ABSTRAK
Latar belakang: Masalah gizi yang paling sering terjadi pada remaja adalah gizi kurus dan gemuk yang disebabkan oleh persepsi body image dan kecenderungan gangguan makan

Tujuan: Tujuan penelitian ini untuk mengetahui hubungan persepsi citra tubuh dan kecenderungan gangguan makan dengan status gizi pada remaja putri di SMA Kota Jambi Tahun 2019.

Metode: Penelitian ini menggunakan desain cross sectional study yang dilaksanakan di 10 SMA Kota Jambi pada bulan Maret - Mei Tahun 2019. Sampel yang digunakan sebanyak 384 remaja putri dengan tehnik cluster random sampling. Pengumpulan data mengunakan alat bantu yaitu Kuesioner BSQ-16 untuk persepsi citra tubuh, Eat-26 untuk kecenderungan gangguan makan, timbangan berat badan dan microtoice untuk pengukuran status gizi indikator IMT/U. Analisis dilakukan dengan analisis univariat dan analisis bivariat (spearman correlation test)

Hasil: Hasil penelitian menunjukan bahwa sebagian besar responden memiliki status gizi normal (83,1\%), body image positif (64,6\%), dan sebanyak (82,8\%) remaja putri tidak memiliki gejala gangguan makan. Analisis korelasi menunjukkan ada hubungan persepsi citra tubuh dengan status gizi indikator IMT/U ( $p=0,000 ; r=0,443)$, namun tidak ada hubungan kecenderungan ganguan makan dengan status gizi indikator IMT/U (p-value 0,657).

Simpulan: Dapat disimpulkan sebagian besar remaja putri memiliki body image positif dan tidak memiliki kecenderungan gangguan makan serta status gizi tergolong normal. Oleh karena itu remaja putri harus percaya diri pada kondisi tubuh sekarang agar tidak berujung gangguan makan dan menyebabkan masalah gizi
\end{abstract}

Kata Kunci : persepsi citra tubuh; kecenderungan gangguan makan; status gizi; remaja putri

\section{PENDAHULUAN}

Fase remaja merupakan fase rentan gizi yang disebabkan oleh percepatan pertumbuhan dan perkembangan tubuh memerlukan energi dan zat gizi yang lebih banyak. Pertumbuhan dan perkembangan yang tidak diimbangi dengan konsumsi zat gizi yang seimbang dapat mengakibatkan defisiensi zat gizi, menjadi alasan mengapa remaja dikategorikan rentan. ${ }^{1}$ Remaja adalah masa yang sangat penting dalam membangun perkembangan mereka dalam dekade pertama kehidupan. ${ }^{2}$ Masa ini ditandai dengan pertumbuhan dan perubahan yang cepat dari masa kanak-kanak menjadi dewasa muda. Perubahan biologis yang 
terjadi selama pubertas remaja meliputi pematangan seksual, peningkatan tinggi badan dan berat badan, akumulasi masa tulang dan perubahan komposisi tubuh. Selama masa remaja terjadi perkembangan identitas pribadi, sistem nilai moral, harga diri, persepsi body image dan kesadaran seksualitas masalah psikososial. Perubahan dramatis bentuk tubuh dan ukuran tubuh banyak terjadi dikalangan remaja, yang mengarah ke perkembangan citra tubuh yang buruk dan gangguan makan. ${ }^{3}$

Masalah gizi yang paling sering terjadi pada remaja adalah kurangnya asupan gizi yang mengakibatkan kurang gizi yaitu terlalu kurus dan dapat terkena anemia karena kekurangan zat besi. Selain itu masalah gizi yang sering muncul adalah kelebihan asupan gizi yang dapat menyebabkan obesitas. Obesitas menjadi ancaman serius bagi kesehatan, kondisi obesitas akan membawa beberapa konsekuensi, seperti diskriminasi dari teman-teman, kesan negatif dari diri sendiri, kurang bisa bersosialisasi dan depresi. ${ }^{4}$

Kasus gizi lebih merupakan salah satu masalah kesehatan yang sedang dihadapi masyarakat dunia. Sebuah penelitian internasional menunjukkan bahwa prevalensi gizi lebih cenderung lebih tinggi dibandingkan dengan prevalensi gizi kurang. Sebanyak $18 \%$ remaja mengalami gizi lebih dan hanya sekitar 3,6\% yang mengalami gizi kurang. ${ }^{5} \mathrm{Di}$ Indonesia, prevalensi kekurusan pada remaja umur16-18 tahun sebesar 8,9\% pada tahun 2010 dan mengalami kenaikan menjadi 9,4\% pada tahun 2013. Sementara itu, prevalensi kegemukan pada anak 1618 tahun secara nasional masih kecil yaitu 1,4\% dan mengalami kenaikan pada tahun 2013 menjadi 7,3\% yang terdiri dari $(5,7 \%$ overweight dan $1,6 \%$ obesitas). Berdasarkan data Riskesdas tahun 2013 di Provinsi Jambi, prevalensi status gizi gemuk sebesar $6,0 \%$ dan prevalensi kurus sebesar $8,0 \%{ }^{6}$ Sedangkan data yang diperoleh dari Dinas Kesehatan Kota Jambi, diketahui sebanyak 807 $(60 \%)$ orang remaja memiliki status gizi kurus dan sebanyak 537 (40\%) mengalami obesitas. ${ }^{7}$ Hal ini menandakan bahwa masalah gizi kurang dan obesitas pada remaja tergolong sangat tinggi.

Persepsi citra tubuh merupakan konsep tubuh seseorang yang meliputi persepsi, pikiran, dan perasaan. Persepsi citra tubuh termasuk tentang kepuasan berat badan. Kepuasan penampilan, kepuasan tubuh, evaluasi penampilan dan orientasi penampilan, perhatian tubuh dan persepsi tubuh. Persepsi citra tubuh tidak hanya tentang konstruksi perseptual tapi juga sebuah refleksi dari sikap dari interaksi terhadap orang lain. Persepsi citra tubuh biasanya diukur dengan melakukan investasi keakuratan estimasi ukuran tubuh relatif terhadap ukuran sebenarnya. ${ }^{8}$ Hasil dari penelitian sebelumnya menunjukan terdapat hubungan antara persepsi citra tubuh dengan status gizi dengan nilai $\mathrm{p}$ $<0,05.9,10$

Ganguan terhadap persepsi citra tubuh dapat mempengaruhi seseorang mengalami masalah gizi. Hal ini disebabkan oleh pola makan yang dilakukan untuk menjaga bentuk tubuh sesuai dengan persepsi citra tubuh yang diharapkan. Kecemasan akan bentuk tubuh membuat remaja sengaja tidak makan yang berujung pada eating disorder (gangguan makan). Gangguan makan adalah gangguan psikologis dan medis yang menyebabkan kelainan serius dalam perilaku makan untuk mengendalikan berat badan atau biasa disebut sebagai suatu gangguan mental yang dapat mempengaruhi remaja. Gangguan makan seperti anorexia nervosa (AN), bulimia nervosa (BN), binge eating disorder (BED) dan eating disorders not otherwise specified (EDNOS) menjadi permasalahan yang berhubungan dengan gangguan persepsi citra tubuh di kalangan remaja. ${ }^{11}$ Hasil penelitian dari Syarafina dan Probosari, (2014), menunjukkan ada hubungan eating disorder dengan status gizi pada remaja putri $(\mathrm{p}=0,01) \cdot{ }^{12}$ Sementara itu, penelitian yang dilakukan oleh Lestari dkk, (2017), juga menunjukkan adaya hubungan bermakna antara eating disorder dengan status gizi dengan nilai $\mathrm{p}=0,002 .{ }^{13}$ Oleh karena itu, tujuan penelitian ini adalah untuk menganalisis hubungan persepsi citra tubuh dan kecenderungan gangguan makan dengan status gizi remaja putri.

\section{METODE}

Penelitian ini merupakan penelitian kuantitatif dengan desain Cross Sectional. Waktu penelitian dilakukan pada bulan Maret - Mei Tahun 2019. Tempat penelitian dilaksanakan di 10 SMA Negeri dan Swasta Kota Jambi. Populasi dalam penelitian ini adalah seluruh remaja putri (siswi) di SMA Kota Jambi yang berjumlah 9.530. Sampel penelitian ini berjumlah 384 orang, yang diambil dengan tehnik cluster random sampling. Pada penelitian ini ditetapkan kriteria inklusi yaitu: (1) siswi yang terdaftar sebagai siswi di SMA Kota Jambi; (2) berada di sekolah saat penelitian dan bersedia menjadi responden; (3) tidak sedang mengalami sakit infeksi yang kronis. Data yang dikumpulkan terdiri dari data status gizi IMT/U, data persepsi citra tubuh dan kecenderungan gangguan makan.

Status gizi pada penelitian ini merupakan kondisi fisik remaja yang ditentukan dengan melakukan pengukuran antropometri secara langsung dengan indikator IMT/U. Hasil ukur pada IMT/U dikategorikan berdasarkan acuan Kepmenkes RI tahun 2010 yaitu: (1) Sangat kurus (<-3SD); (2) Kurus (-3 SD sampai < -2SD); (3) 
Normal (-2 SD sampai <1SD); (4) Gemuk ( $\geq 1$ SD sampai 2SD); (5) Obesitas (>2SD). ${ }^{14}$

Persepsi citra tubuh merupakan pandangan remaja putri terhadap penampilan dan bentuk fisiknya. Data persepsi citra tubuh diperoleh dari wawancara menggunakan kuesioner Body Shape Questionnaire (BSQ-16). Mengacu kepada penelitian Hastuti tahun 2013, maka persepsi citra tubuh dikategorikan menjadi persepsi citra tubuh positif $(<38)$ dan persepsi citra tubuh negatif $(\geq 38) .{ }^{15}$

Gangguan makan adalah penyimpangan perilaku makan remaja putri seperti mengurangi kadar makanan dengan ekstrim atau makan terlalu banyak yang ekstrem. Data gangguan makan diperoleh dari wawancara menggunakan kuesioner Eating Attitudes Test (EAT-26). Selanjutnya, data dikategorikan menjadi Tidak berisiko mengalami gangguan makan $(<20)$ dan Berisiko mengalami gangguan makan $(\geq 20) .{ }^{16}$

Data yang dikumpulkan kemudian dianalis dengan langkah-langkah editing, coding, scoring, dan analyzing. Analisis univariat didapatkan untuk mendapatkan gambaran tentang distribusi frekuensi dari semua variabel independen (persepsi citra tubuh dan kecenderungan gangguan makan) dan dependen (status gizi). Sementara itu, untuk analisis bivariat data yang digunakan adalah data numerik dan menggunakan analisis correlation (spearmen test) dengan $\alpha=0,05$.

\section{HASIL}

Tabel 1. Distribusi Frekuensi Responden Berdasarkan Usia pada Remaja Putri di SMA Kota Jambi Tahun 2019

\begin{tabular}{ccc}
\hline Usia (tahun) & Frekuensi & Persentase \\
\hline $14-15$ & 109 & 28,4 \\
$16-17$ & 271 & 70,6 \\
$18-21$ & 4 & 1,0 \\
Total & $\mathbf{3 8 4}$ & $\mathbf{1 0 0 , 0}$ \\
\hline
\end{tabular}

Kelompok umur diketegorikan berdasarkan kriteria pertumbuhan dan perkembangan remaja. ${ }^{17}$ Tabel 1 dapat diketahui bahwa responden terbanyak berumur 16-17 tahun yaitu sebanyak 271 (70,5\%) responden. Distribusi frekuensi subjek penelitian berdasarkan status gizi indikator IMT/U dapat dilihat pada Tabel 2 .

Tabel 2. Distribusi Frekuensi Responden Berdasarkan Status Gizi Indikator IMT/U pada Remaja Putri di SMA Kota Jambi Tahun 2019

\begin{tabular}{lcc}
\hline $\begin{array}{l}\text { Status Gizi } \\
\text { Indikator IMT/U }\end{array}$ & Frekuensi & Persentase \\
\hline Sangat kurus & 1 & 0,3 \\
Kurus & 10 & 2,6 \\
Normal & 319 & 83,1 \\
Gemuk & 39 & 10,1 \\
Obesitas & 15 & 3,9 \\
Total & $\mathbf{3 8 4}$ & $\mathbf{1 0 0 , 0}$ \\
\hline
\end{tabular}

Status gizi remaja putri indikator IMT/U dikelompokkan menjadi 5 kategori yaitu sangat kurus, kurus, normal, gemuk dan obesitas. Berdasarkan Tabel 2 dapat diketahui bahwa sebagian besar responden memiliki status gizi normal yaitu $319(83.1 \%)$ responden. Distribusi Frekuensi responden penelitian berdasarkan persepsi citra tubuh dapat dilihat pada Tabel 3.

Tabel 3. Distribusi Frekuensi Responden Berdasarkan Persepsi Citra Tubuh pada Remaja Putri di SMA Kota Jambi Tahun 2019

\begin{tabular}{lcc}
\hline Persepsi Citra Tubuh & Frekuensi & Persentase \\
\hline Citra tubuh positif & 248 & 64,6 \\
Citra tubuh negative & 136 & 35,4 \\
Total & $\mathbf{3 8 4}$ & $\mathbf{1 0 0 , 0}$ \\
\hline
\end{tabular}

Berdasarkan Tabel 3 dapat diketahui responden dengan persepsi citra tubuh positif sebanyak $248(64,6 \%)$ responden dan persepsi citra tubuh negatif sebanyak $136(35,4 \%)$ responden. Rerata skor persepsi citra tubuh secara keseluruhan yaitu 35. Distribusi frekuensi subjek penelitian berdasarkan kecenderungan gangguan makan pada remaja putri di SMA Kota Jambi Tahun 2019 dapat dilihat pada Tabel 4.

Tabel 4. Distribusi Frekuensi Responden Berdasarkan Kecenderungan Gangguan Makan pada Remaja Putri di SMA Kota Jambi Tahun 2019

\begin{tabular}{lcc}
\hline Kecenderungan Gangguan Makan & Frekuensi & Persentase \\
\hline Tidak ada gejala gangguan makan & 318 & 82,8 \\
Adanya gejala gangguan makan & 66 & 17,2 \\
Total & $\mathbf{3 8 4}$ & $\mathbf{1 0 0 , 0}$ \\
\hline
\end{tabular}

Tabel 4 dapat dilihat dari kecenderungan gangguan makan responden yang tidak memiliki gejala gangguan makan sebanyak $318(82,8 \%)$ responden dan yang memiliki gejala gangguan makan sebanyak $66(17,2 \%)$ responden. Sementara itu rerata skor kecenderungan gangguan makan secara keseluruhan yaitu 12. Hasil analisis korelasi 
antara persepsi citra tubuh dan status gizi indikator IMT/U dapat dilihat pada Tabel 5.

Berdasarkan tabel 5 dapat diketahui bahwa terdapat hubungan persepsi citra tubuh dengan status gizi indikator IMT/U $(p=0,000 ; \quad \mathrm{r}=0,443)$. Sementara itu, hasil analisis korelasi antara kecenderungan gangguan makan dengan status gizi indikator IMT/U dapat dilihat pada Tabel 6. Hasil penelitian ini menunjukkan bahwa tidak terdapat hubungan kecenderungan gangguan makan dengan status gizi indikator IMT/U $(p=0,657)$.

Tabel 5. Hubungan Persepsi Citra Tubuh dengan Status Gizi Indikator IMT/U pada Remaja Putri SMA Kota Jambi tahun 2019

\begin{tabular}{lccc}
\hline \multicolumn{1}{c}{ Variabel } & Mean & Std Deviasi & $\boldsymbol{p}$-value \\
\hline Persepsi Citra Tubuh & 34,60 & 13,94 & $p=0,000$ \\
Status Gizi Indikator IMT/U & $-0,08$ & 1,04 & \\
\hline
\end{tabular}

Tabel 6. Hubungan Kecenderungan Gangguan Makan dengan Status Gizi Indikator IMT/U pada Remaja Putri SMA Kota Jambi tahun 2019

\begin{tabular}{lccc}
\hline \multicolumn{1}{c}{ Variabel } & Mean & Std Deviasi & $\boldsymbol{p}$-value \\
\hline Kecenderungan Gangguan Makan & 11,85 & 8,68 & $p=0,657$ \\
Status Gizi Indikator IMT/U & $-0,08$ & 1,039 & \\
\hline
\end{tabular}

\section{PEMBAHASAN}

\section{Hubungan Persepsi Citra Tubuh dengan Status} Gizi indikator IMT/U

Pada penelitian ini diketahui bahwa sebagian besar remaja putri memiliki status gizi normal yaitu sebanyak $83,1 \%$ dengan rerata nilai $z$-score $-0,272$. Penelitian ini sejalan dengan penelitian sebelumnya di Indonesia yang menunjukkan bahwa sebagian besar remaja putri memiliki status gizi normal. ${ }^{18,19}$ Sementara itu, penelitian di beberapa negara juga menunjukkan bahwa remaja putri di perkotaan memiliki status gizi normal. ${ }^{20}$

Status gizi normal berperan dalam mewujudkan kesehatan reproduksi yang akan membantu remaja mencapai pertumbuhan dan perkembangan yang optimal. ${ }^{21}$ Status gizi yang baik pada usia remaja juga sangat penting agar masa kehamilannya nanti tidak berisiko. Calon ibu yang tinggi badannya kurang dari $(145 \mathrm{~cm})$ berisiko tinggi mengalami kesulitan pada waktu melahirkan sedangkan ibu yang mempunyai riwayat kurang berat badan $(<45 \mathrm{~kg})$ cenderung melahirkan lebih cepat (premature) dengan risiko berat badan lahir rendah serta gangguan tumbuh kembang anak. ${ }^{22}$

Berdasarkan analisis spearman diperoleh nilai korelasi sebesar $p=0,000$ yang artinya ada hubungan antara persepsi citra tubuh dengan status gizi indikator IMT/U pada remaja putri di SMA Kota Jambi. Menurut Cahyaningrum (2013) terdapat hubungan persepsi citra tubuh dengan status gizi hal tersebut dikarenakan status gizi tidak hanya dipengaruhi oleh asupan makanan dan infeksi saja tetapi status gizi juga dipengaruhi oleh faktor lain seperti persepsi citra tubuh. Terbentuknya konsep diri berupa persepsi citra tubuh pada remaja, juga menyebabkan kebanyakan remaja kekurangan asupan makanan karena melakukan diit yang salah. ${ }^{23}$
Konsep persepsi citra tubuh yang negatif akan berdampak pada status gizi remaja sebab persepsi citra tubuh merupakan salah satu faktor penting yang berkaitan dengan status gizi seseorang. ${ }^{24}$ Remaja putri berkeinginan untuk memiliki tubuh yang tinggi dan langsing dengan cara melakukan diet ketat, sehingga beresiko gizi buruk. ${ }^{10}$

Hasil penellitian ini sejalan dengan penelitian sebelumnya yang menunjukan bahwa terdapat hubungan antara persepsi citra tubuh dengan status gizi. ${ }^{18,25}$ Sementara itu, penelitian yang dilakukan oleh Ahadzadeh et al (2018) juga menunjukan bahwa BMI memiliki korelasi negatif dengan persepsi citra tubuh $(\beta=-0,090, p<0,005) .{ }^{26}$

Berbagai perubahan fisik yang terjadi pada remaja merupakan proses yang alamiah, yang akan dilalui oleh semua individu, namun seringkali ketidaktahuan remaja terhadap perubahan itu sendiri membuat mereka hidup dalam kegelisahan dan perasaan cemas. Ditambah dengan perubahan konsep diri dan pencarian identitas diri, maka akan banyak permasalahan yang muncul jika mereka tidak dibimbing dengan baik untuk melewati masa tersebut. Proses pencarian identitas diri tersebut harus mendapat bimbingan dari orang sekelilingnya agar mereka dapat tumbuh menjadi remaja yang bertanggung jawab. ${ }^{22}$

Persepsi citra tubuh adalah persepsi seseorang tentang tubuhnya, mencakup pikiran, presepsi perasaan, emosi, imajinasi, penilaian, sensasi fisik, kesadaran dan perilaku mengenai penampilan dan bentuk tubuhnya dipengaruhi oleh idealisasi pencitraan tubuh di masyarakat dan interaksi sosial seseorang dalam lingkungannya dan dapat mengalami perubahan. Pernyataan mengenai persepsi citra tubuh tersebut, dapat disimpulkan bahwa persepsi citra tubuh adalah gambaran atau 
konsep pribadi seseorang akan penampilan fisiknya. ${ }^{27}$ Oleh karena itu perlu adanya bimbingan orang tua terhadap remaja putri yang tidak memiliki kepuasaan terhadap bentuk tubuhnya dan perlu adanya penyuluhan mengenai status gizi pada remaja putri.

\section{Hubungan Kecenderungan Gangguan Makan dengan Status Gizi indikator IMT/U}

Hasil analisis korelasi menunjukkan bahwa tidak terdapat hubungan kecenderungan gangguan makan dengan status gizi indikator IMT/U $(p=0,657)$. Hasil penelitian ini sejalan dengan penelitian sebelumnya dengan uji regresi logistic yang menunjukkan bahwa tidak ada hubungan signifikan antara gangguan makan dengan status gizi $(p=0,068) .{ }^{27}$ Penyebab tidak adanya hubungan kecenderungan gangguan makan dengan status gizi hal tersebut dikarenakan status gizi tidak hanya dipengaruhi oleh gangguan makan tetapi status gizi juga dipengaruhi oleh asupan makan dan infeksi. ${ }^{28}$ World Health Organization (WHO) pada tahun 1987 mendeklarasikan gangguan makan sebagai isu penting. Sekitar delapan juta orang di seluruh dunia mengalami eating disorder, seperti anorexia nervosa, bulimia nervosa, dan binge eating. ${ }^{29}$

Eating disorder merupakan problem utama yang dialami remaja yang nampak pada perubahan dalam hal perilaku makan menjadi tidak baik, persepsi bentuk tubuh (persepsi citra tubuh) negatif dan ketidaktepatan dalam pengaturan berat badan. ${ }^{30}$ Terdapat dua faktor yang mempengaruhi eating disorder pada remaja, yaitu: (1) jenis kelamin, dimana remaja putri memiliki keinginan kurus, kecil, langsing; dan (2) pengetahuan, dimana pengetahuan (kognitif) berperan penting bagi individu dalam mengambil tindakan. ${ }^{13}$

Gangguan pola makan anoreksia nervosa dan bulimia nervosa banyak terjadi dikalangan remaja, terutama remaja putri. Adalah hal yang wajar jika remaja memperhatikan penampilan fisik mereka. Namun, bila berlebihan maka bisa terjadi obsesif dan mempengaruhi pola makan mereka. Pada awalnya, penderita biasanya hanya mencoba menurunkan berat badan atau ingin membentuk tubuh ideal, namun keinginan itu dalam jangka waktu lama akan berubah menjadi obsesif dan tidak terkendali. ${ }^{31}$

Pada penelitian ini, ditemukan bahwa sebanyak $77,9 \%$ remaja putri berisiko megalami gangguan makan bulimia and food preoccupation dengan pernyataan bahwa makanan membuat mereka senang dan makan banyak disaat mendapatkan makanan kesukaan, serta makan banyak saat sedang stress. Gangguan pola makan ini ditandai dengan usaha untuk memuntahkan kembali secara terus-menerus apa yang telah dimakan sebelumnya. Oleh karena itu, perlu adanya bimbingan dari orang tua dalam prilaku makan sehingga tidak menimbulkan masalah gizi, serta perlu upaya promotif dari pihak kesehatan untuk meningkatkan penyuluhan gizi dan kesehatan remaja.

\section{SIMPULAN}

Terdapat hubungan persepsi citra tubuh dengan status gizi indikator IMT/U. Tidak terdapat hubungan kecenderungan gangguan makan dengan status gizi indikator IMT/U pada Remaja Putri.

Diharapkan remaja putri untuk meningkatkan pengetahuan tentang masalah gizi pada remaja kesehatan. Remaja putri yang memiliki status gizi normal agar mempertahankan status gizinya. Remaja yang memiliki status gizi kurang disarankan untuk menambah asupan makanan yang dikonsumsi dan untuk remaja yang memiliki status gizi lebih agar dapat mengurangi asupan makanan dan sebaiknya menerapkan pola makan yang benar, aktivitas fisik yang baik dengan cara melakukan olahraga rutin seminggu tiga kali selama 30 menit. selain itu, diharapkan kepda remaja lebih percaya diri pada kondisi tubuh yang dimiliki saat ini, serta tidak terlalu mempedulikan penilaian negatif dari orang lain disekitar.

\section{UCAPAN TERIMA KASIH}

Peneliti mengucapkan terima kasih kepada pihak SMA Negeri dan Swasta Kota Jambi yang telah memberikan izin sehingga dapat terlaksananya penelitian ini. Selain itu, peneliti juga mengucapkan terimakasih kepada STIKes Baiturrahim yang telah memberikan dukungan materil sehingga penelitian dapat berjalan dengan baik.

\section{DAFTAR PUSTAKA}

1. Mardalena I. Dasar-Dasar Ilmu Gizi dalam Keperawatan. Pustaka Baru Press: Yogyakarta: 2017.

2. Kemenkes RI. Buku Panduan untuk Siswa: Aksi bergizi, hidup sehat sejak sekarang untuk remaja kekinian. Jakarta: Kementerian Kesehatan RI: 2019.

3. Brown JE. Nutrition Through the Life Cycle. Wadsworth: USA: 2013.

4. Waryana. Gizi Reproduksi. Pustaka Rihama: Yogyakarta: 2010.

5. Laus MF, Braga Costa TM, Almeida S. Body Image dissatisfaction and its relationship with physical activity and body mass index in Brazilian adolescent. Jornal Brasileiro de psiquiatria, 2011; 60(4): 315-20.

6. Kemenkes RI. Riset Kesehatan Dasar. Jakarta : Kemenkes RI: 2013. 
7. Dinas Kesehatan Kota Jambi. Rekapitulasi Hasil Penjaringan Peserta Didik di Wilayah Puskesmas. Jambi: Dinkes Kota Jambi: 2018.

8. Grogan, S. Body image understanding body dissatisfaction in men, women and children. Newyork: Routledge: 2008.

9. Nurcahyani F. Hubungan antara body image dan konsumsi makanan dengan status gizi remaja putri. Jember : Universitas Jember : 2014. Skripsi.

10. Widianti N, Candra A. Hubungan antara body image dan prilaku makan dengan status gizi remaja putri di SMA Theresiana Semarang. Journal of Nutrition College, 2012; 1(1) : 398404.

11. Chisuwa N, O'Dea JA. Body Image and eating disorders among Japanese adolescents. a review of the Literature. Appetite, 2010; 54: 5-15.

12. Syarafina A, Probosari E. Hubungan eating disorder dengan status gizi pada remaja putri di modeling agency semarang. Journal of Nutrition College, 2014; 3(2): 325-330.

13. Lestari AT, Yogisutanti G, Sobariah E. Hubungan tingkat stres dan eating disorder dengan status gizi pada remaja perempuan di SMA negeri 1 Ciwidey. Immanuel Jurnal Ilmu Kesehatan, 2017; 12 (2): 128-136.

14. Kepmenkes RI. Standar Antopometri Penilaian Status Gizi Anak. Jakarta: Kemenkes RI: 2010.

15. Hastuti J. Anthropometry and body composition of indonesia adults: an evaluastion of image, eating behavior, and physical activity. Queensland: Faculty of Health Queensland University of Technology: 2013. Disertasi

16. Garner DM, Garfinkel PE. The eating attitudes test: an index of the symptoms of anorexia nervosa. Psychol Med, 1979; 9(2) :273-9.

17. Patimah S. Gizi Remaja Putri. Bandung: PT Refika Aditama: 2017.

18. Yusintha AN, Adriyanto A. Hubungan antara perilaku makan dan citra tubuh dengan status gizi remaja putri usia 15-18 tahun. Amerta Nutrition, 2018; 2(2): 147-154.

19. Yuniarti A. hubungan pengetahuan gizi, kebiasaan makan, dan gangguan makan dengan persen lemak tubuh pada penari hip-hop remaja wanita. Institut Pertanian Bogor Bogor. 2016. Skripsi.
20. Benazeera, Jayaraman U. Association between eating habits and body mass index (BMI) of adolescents. International Journal of Medical Science and Public Health, 2014; 3(8): 940943.

21. Badriah DL. Gizi dalam Kesehatan Reproduksi. Bandung: Refika Aditama: 2011.

22. Proverawati A, Kusumawati E. Ilmu Gizi.Yogyakarta: Muha Medika: 2017.

23. Cahyaningrum HD. Hubungan antara body image dengan status gizi pada remaja putri kelas XI IPS di SMA Batik 1 Surakarta. Universitas Muhammadiyah Surakarta: 2013. Diploma Thesis.

24. Magdalena N. Hubungan antara body image dengan status gizi remaja putri di SMA katolik Frateran Malang. Malang: Universitas Brawijaya: 2013. Skripsi.

25. Bimantara MD, Adriani $M$ \& Suminar DR. Hubungan citra tubuh dengan status gizi pada siswi di SMA negeri 9 Surabaya. Amerta Nutrition, 2019; 3(2), 85-88.

26. Ahadzadeh AS, Rafik-Galea S, Alavi M, Amini M. Relationship between body mass index, body image, and fear of negative evaluation: moderating role of self-esteem. Health Psychol Open, 2018; 5(1): 1-8.

27. Sada M, Hadju V, Dachlan DM. Hubungan body image, pengetahuan gizi seimbang, dan aktifitas fisik terhadap status gizi mahasiswa politeknik kesehatan Jayapura. Media Gizi Masyarakat Indonesia, 2012; 2(1): 44-48.

28. Supariasa IDN, Bakri B, Fajar I. Penilaian Status Gizi. Jakarta: Penerbit Buku Kedokteran EGC: 2002.

29. Levicka K. Kovalcikova N, Kovacova L. Incidence of eating disorders in family environment in high school adolescents. Procedia - Social and Behavioral Sciences, 2014; 132: 391 - 397.

30. Ando, T., Ichimaru, Y., Konjiki, F., Shoji, M., Komaki, G. Variations in the preproghrelin gene correlate with higher body mass index, fat mass, and body dissatisfaction in young japanese women. Am J Clin Nutr, 2007; 86 (1): 25-32.

31. Susilowati, Kuspriyanto. Gizi Dalam Daur Kehidupan. Bandung: PT Refika Aditama: 2016. 